\title{
University Contributors
}

\author{
Yousef Ahmed Alomi iD \\ The Former General Manager of General Administration of Pharmaceutical Care and Former Head, National Clinical \\ Pharmacyand Pharmacy Practice and Pharmacy $R$ and D Administration, Ministry of Health, Riyadh, SAUDI ARABIA.
}

The International Journal of Pharmacology and Clinical Sciences (IJPCS) started collaboration with national and international universities in the Kingdom of Saudi Arabia, Gulf and in Middle Eastern countries in addition to East Asia, India and Africa. The collaboration is part of the journal's goals including Saudi Vision 2030 which encourages all students and young researchers to publish their research; new programs and new initiatives; innovative projects within medical, pharmacy and all related health sciences. Each collaborative university will send the names of nominees including the names of dean of the college and publication coordinator. All nominated universities will be posted on the journal's website as the university contributors. All researchers may contact IJPCS administrators through the university coordinator. The journal's consultation team will receive the manuscripts. The team will choose the best research for publication. The team will also help the researchers to correct the manuscript related publications if it possible. If the manuscript cannot be corrected, then the consultation team will reject the manuscript and inform the researchers. The manuscripts will enter officially through the journal's procedures of manuscripts submission.

\section{ORCID ID}

Yousef Ahmed Alomi (D) https://orcid.org/0000-0003-1381-628X

*Correspondence to:

Dr. Yousef Ahmed Alomi, Email: yalomi@gmail.com DOI: 10.5530/ijpcs.2019.8.1

Copyright: @ the author(s),publisher and licensee International Journal of Pharmacology and Clinical Sciences. This is an open-access article distributed under the terms of the Creative Commons Attribution Non-Commercial License, which permits unrestricted non-commercial use, distribution, and reproduction in any medium, provided the original work is properly cited.

This is an open access article distributed under the terms of the Creative Commons Attribution-NonCommercial-ShareAlike 4.0 License

Access this article online

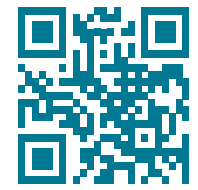

www.ijpcs.net 